\title{
Application of Long Noncoding RNAs in Osteosarcoma: Biomarkers and Therapeutic Targets
}

\author{
Zhihong Lia Pengcheng Dou ${ }^{a}$ Tang Liu ${ }^{a}$ Shasha He \\ aDepartment of Orthopaedics, the Second Xiangya Hospital, Central South University, Changsha, \\ Hunan, bepartment of Oncology, the Second Xiangya Hospital, Central South University, Changsha, \\ Hunan, P.R. China
}

\section{Key Words}

Osteosarcoma $\cdot$ Long noncoding RNA • Biomarkers • Therapeutic target

\begin{abstract}
Osteosarcoma is the most common primary bone malignancy in children and adolescents. Although improvements in therapeutic strategies were achieved, the outcome remains poor for most patients with metastatic or recurrent osteosarcoma. Therefore, it is imperative to identify novel and effective prognostic biomarker and therapeutic targets for the disease. Long noncoding RNAs (IncRNAs) are a novel class of RNA molecules defined as transcripts $>200$ nucleotides that lack protein coding potential. Many IncRNAs are deregulated in cancer and are important regulators for malignancies. Nine IncRNAs $(91 \mathrm{H}, \mathrm{BCAR4}$, FGFR3-AS1, HIF2PUT, HOTTIP, HULC, MALAT-1, TUG1, UCA1) are upregulated and considered oncogenic for osteosarcoma. Loc285194 and MEG3 are two IncRNAs downregulated and as tumor suppressor for the disease. Moreover, the expressions of LINC00161 and ODRUL are associated with chemo-resistance of osteosarcoma. The mechanisms for these IncRNAs in regulating development of osteosarcoma are diverse, e.g. ceRNA, Wnt/ $\beta$-catenin pathway, etc. The IncRNAs identified may serve as potential biomarkers or therapeutic targets for osteosarcoma.
\end{abstract}

\section{Introduction}

(C) 2017 The Author(s)

Published by S. Karger AG, Basel

The human transcriptome consists of protein-coding genes and non-coding RNAs (ncRNAs). Long non-coding RNAs (lncRNAs) are in the range from $200 \mathrm{nt}$ to $100 \mathrm{~kb}$ [1]. Most IncRNAs, like mRNAs, are transcribed by RNA polymerase II and are capped, polyadenylated, and spliced. A major difference between IncRNAs and mRNAs is that IncRNAs have little if any protein coding potential. Approximately 7,000-23,000 lncRNAs have been identified in vivo, which is significantly higher than the number of protein-coding genes [2]. In relationship

Z. Li and P. Dou are the co-first authors, they contributed equally to the work.

Tang Liu, MD., PhD,

Shasha He, MD., PhD

KARGER
Department of Orthopaedics, the Second Xiangya Hospital, Central South University, Changsha, Hunan, 410011, (P.R. China); Department of Oncology, the Second Xiangya Hospital, Central South University, Changsha, Hunan, 410011, (P.R. China)

E-Mail liutang1204@csu.edu.cn / laishiweisha611@126.com 
with the nearest protein-coding genes, IncRNAs can be classified as (i) sense, (ii) antisense, (iii) bidirectional, (iv) intronic, and (v) intergenic [3-5]. LncRNAs in the cytoplasm may regulate the stability and the translation of mRNAs, act as the precursor of microRNAs (miRNA), or compete the endogenous RNAs (CeRNAs), regulate the distribution of miRNAs on their target. lncRNAs in the nucleus can act at epigenetic level and at genetic level through interacting with the transcription preinitiation complex at the promoter. $[3,4,6-8]$

LncRNAs can positively or negatively regulate gene expression through multiple mechanisms. For epigenetic and transcription regulation, lncRNAs may recruit transcription factors or chromatin-modifying complexes to their DNA targets, form heterogeneous nuclear ribonucleoprotein (hnRNP) complexes, act as decoys to sequester RNA-binding proteins (RBPs) and microRNAs, or directly interact with RNAs and DNAs by base pairing. For posttranscriptional regulation, IncRNAs may regulate the stability and the translation of mRNAs, act as the precursor of microRNAs (miRNA), compete the endogenous RNAs (CeRNAs), or regulate the distribution of miRNAs on their target [3, 4, 6-8] (Fig. 1) .

Osteosarcoma is the most common type of highly malignant bone tumor in children and adolescents. It arises from mesenchymal cells and is pathologically characterized by spindle cells and aberrant osteoid formation $[9,10]$. 80\% of patients who do not have distant metastases at initial diagnosis will become long-term survivors. However, patients with metastatic or recurrent disease have less than $20 \%$ chance of long-term survival despite aggressive therapies[11]. Identification of clinically relevant biomarkers for prognosis is therefore urgently need for these patients. In the past few years, a number of potential molecular markers have been identified while specific diagnostic biomarker for osteosarcoma is not yet been confirmed [12-14]. Increasing evidences indicate that many of the genomic mutations in cancer reside in regions that do not encode proteins but are often transcribed into IncRNAs. Aberrant expression of IncRNAs is also associated with different cancer types [15-29]. As discussed in the present review, lncRNAs play important role in the cellular function and transformation activity in osteosarcoma (Fig. 2); oncogenic lncRNA: 91H, BCAR4, FGFR3-AS1, HIF2PUT, HOTTIP, HULC, MALAT-1, TUG1, UCA1; tumor suppressor IncRNA: Loc285194, MEG3; drug associated IncRNA, LINC00161,ODRUL. These IncRNA may be potential biomarkers and therapeutic targets for the disease.

\section{Oncogenic LncRNAs in Osteosarcoma}

\section{H19 antisense RNA (91H)}

$91 \mathrm{H}$ is located on the position of the H19/IGF2 locus with $119 \mathrm{~kb}$ in length. $91 \mathrm{H}$ was overexpressed in human breast cancer and was involved in the regulation of IGF2 expression[30]. Reduced 91H expression was also demonstrated in high-grade invasive esophageal squamous cell carcinoma and colorectal cancer. Knockdown of 91H inhibited the proliferation, migration, and invasiveness of colorectal cancer cells [31,32] .

$91 \mathrm{H}$ expression was notably increased in osteosarcoma patients and cell lines as compared to healthy controls and normal human bone cell lines. Elevated expression of $91 \mathrm{H}$ was significantly correlated with advanced clinical stage. Furthermore, $91 \mathrm{H}$ was an independent prognostic factor for overall survival in osteosarcoma patients after treatments. Knockdown of $91 \mathrm{H}$ inhibited osteosarcoma cells proliferation and promoted apoptosis in vitro [33] while the underlying mechanism is not clear.

Breast cancer antiestrogen resistance 4 (BCAR4)

BCAR4 was identified using functional genetic screens to isolate genes capable of inducing antiestrogen resistance in human breast cancer cells [34]. BCAR4 contributes to antiestrogen resistance and promotes breast cancer proliferation and metastasis through noncanonical Hedgehog/GLI2 pathway [35-37].

BCAR4 is upregulated in osteosarcoma tissues and its overexpression correlated with poor prognosis of osteosarcoma patients. Knockdown of BCAR4 inhibited proliferation and 


\section{Cellular Physiology Cell Physiol Biochem 2017;42:1407-1419 \begin{tabular}{l|l} 
DOI: 10.1159/000479205 & $\begin{array}{l}\text { O 2017 The Author(s). Published by S. Karger AG, Basel } \\
\text { www.karger.com/cpb }\end{array}$
\end{tabular}

Fig. 1. Gene regulation mechanisms by IncRNAs. The major transcriptional and post-transcription gene regulation events influenced by lncRNAs. (1) LncRNAs control the binding of chromatin-modifying complexes to specific genomic loci and regulate gene expression at epigenetics level. (2) LncRNAs compete for binding with splicing regulatory proteins (e.g. SR) to modulate alternative splicing of pre-mRNAs. (3) LncRNAs alter the activity of transcription factors (TF) by acting as co-activators or repressors on the regulation of gene expression. (4) Formation of IncRNAs-mRNA hybrid protects mRNA from decay and increases mRNAs stability. (5) IncRNAs functions jointly with other proteins, e.g. Staufen 1 to promote mRNA decay. (6) IncRNAs enhance ribosome binding to mRNA and thus promote translation. (7) IncRNAs recruit translation repressors, e.g. Rck, leading to translation repression. (8) Some IncRNAs produce miRNAs for regulating gene expression.

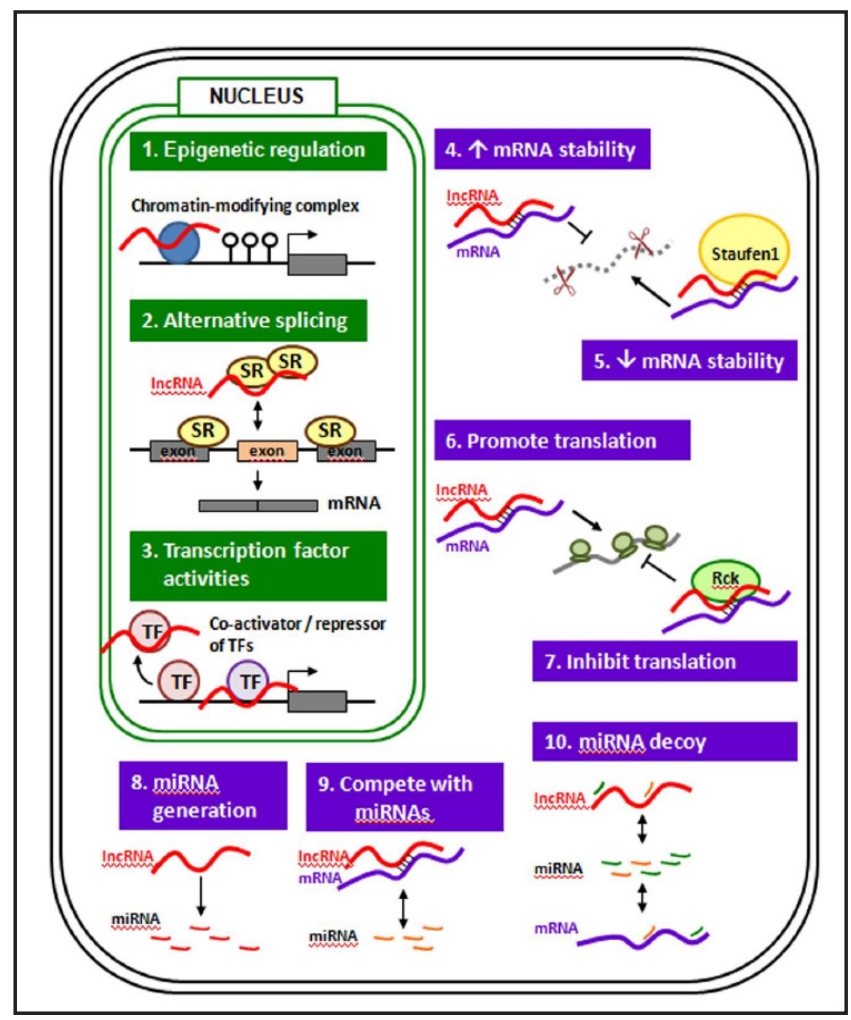

(9) IncRNAs compete with miRNAs for binding with target mRNAs. (10) Some lncRNAs can serve as sponges/decoys for miRNAs in the regulation of miRNAs level and gene expression.

migration of osteosarcoma cells in vitro and tumorigenesis and metastasis in vivo through GLI2 target genes. The oncogenic effect of BCAR4 in osteosarcoma is by activating GLI2dependent gene transcription through direct promoter interaction [38]. The mechanism, however, differs from those found in breast cancer in which BCAR4 is associated with GLI2 in the protein complexes [39].

FGFR3 antisense transcript 1 (FGFR3-AS1)

FGFR3-AS1, initially named as lncRNA-BX537709, is oriented in antisense direction and formed a 'tail-to-tail' pairing pattern with 1053 nt full complementarity to FGFR3. FGFR3-AS1 is first reported to be upregulated in osteosarcoma and is correlated with poor prognosis. The expression of FGFR3-AS1 and FGFR3 is positively correlated in osteosarcoma tissues. Knockdown of FGFR3-AS1 inhibited the proliferation and cell cycle progression of osteosarcoma cells in vitro. Moreover, knockdown of FGFR3-AS1 inhibited xenograft tumor growth of osteosarcoma cells in vivo. Through antisense pairing with FGFR3 3'UTR, FGFR3AS1 increases mRNA stability and expression of FGFR3, a protein known to be important in cancer development $[40,41]$.

\section{HIF-2 $\alpha$ promoter upstream transcript (HIF2PUT)}

HIF2PUT, previously named as TCONS_00004241, is located on chromosome 2p21, on the antisense side of the promoter upstream region of a cancer-associated mRNA, hypoxiainducible factor-2 $\alpha$ (HIF-2 $\alpha$ ) [42-44]. The lncRNA belongs to a class of lncRNAs known as promoter upstream transcripts (PROMPTs), that regulate the transcriptional activity of host genes $[45,46]$. The expression of HIF2PUT was significantly correlated with HIF-2 $\alpha$ in colorectal cancer tissues. Knockdown of HIF2PUT suppressed the expressions of HIF-2 $\alpha$ and the stemness genes, OCT4, SOX2, and CD44. The knockdown also inhibited the cancer stem cells properties in colorectal cell lines, including proliferation, self-renewal, migration, and invasion abilities [42]. 
Fig. 2. IncRNAs play important role in the cellular function and transformation activity in osteosarcoma. Oncogenic IncRNA: 91H, BCAR4, FGFR3-AS1, HIF2PUT, HOTTIP, HULC, MALAT-1, TUG1, UCA1; tumor suppressor IncRNA: Loc285194, MEG3; drug associated IncRNA, LINC00161, ODRUL. These IncRNA may be potential biomarkers and therapeutic targets for the disease.

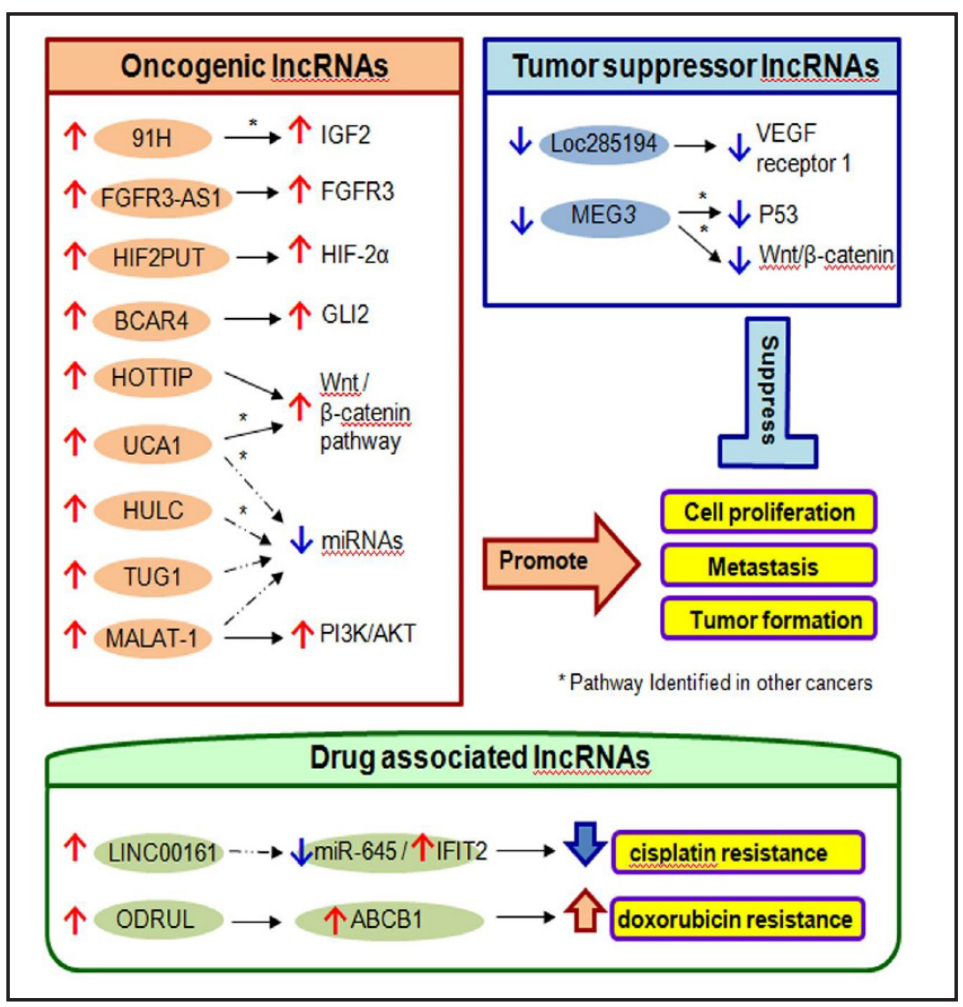

Compared with non-cancerous bone tissues, HIF- $2 \alpha$ mRNA and HIF2PUT expressions were both significantly upregulated in osteosarcoma tissues. In addition, HIF2PUT expression levels were positively correlated with HIF- $2 \alpha$. Moreover, osteosarcoma patients with HIF$2 \alpha$ mRNA and/or HIF2PUT over-expression frequently had large tumor size, advanced clinical stage, positive distant metastasis, and shorter overall and disease-free survival. Overexpression of HIF2PUT markedly inhibited cell proliferation and migration, decreased the percentage of CD133 expressing cells, and impaired the osteosarcoma self-renewal of the osteosarcoma MG63 cells $[43,44]$. However, the HIF2PUT/HIF-2 $\alpha$ pathway is yet to be confirmed in osteosarcoma.

\section{HOXA transcript at the distal tip (HOTTIP)}

HOTTIP was previously considered as a negative prognostic factor in patients with liver cancer, gastric cancer, pancreatic cancer, non-small cell lung cancer, tongue squamous cell carcinoma, colorectal cancer [47-51]. Increased expression of HOTTIP was associated with enhanced cancer cell proliferation and metastasis. The action mechanism for HOTTIP is at least through regulating of (i) RNA-binding proteins (RBPs), e.g. WDR5/MLL complex; (ii) EMT bio-markers, e.g. E-cadherin, vimentin, snail 1, etc.; (iii) HOXA genes, e.g HOXA13 [52]. Inhibition of HOTTIP potentiated the antitumor effects of gemcitabine in vitro and in vivo [53].

HOTTIP was overexpressed in osteosarcoma tissues compared with adjacent nontumorous tissues. Elevated HOTTIP expression was associated with an advanced clinical stage and distant metastasis. Additionally, knockdown of HOTTIP suppressed osteosarcoma cell proliferation, migration and invasion in vitro. Increased expression of HOTTIP was correlated with chemoresistance in osteosarcoma by activating the Wnt/ $\beta$-catenin pathway $[54,55]$.

Highly up-regulated in liver cancer (HULC)

HULC is located on chromosome 6p24.3. The HULC transcript is about $500 \mathrm{nt}$ long, localizes to the cytoplasm and associates with ribosomes [56]. HULC was initially found to 
be strongly overexpressed in human hepatocellular carcinoma [56-58], gastric cancer [59], B-cell lymphoma [60], colorectal cancer [61], in which it serves as an oncogene.

HULC is capable of promoting tumor growth, migration, invasion, angiogenesis in hepatocellular carcinoma and colorectal cancer cells $[61,62]$. The lncRNA acts as a miRNA sponge that binds to and reduces the expression of a number of miRNAs, including miR200a-3p, miR-107 [63, 64]. HULC promotes tumor angiogenesis in liver cancer through miR-107/E2F1/SPHK1 signaling [62]. It also suppresses miR-9 targeting of PPARA mRNA by eliciting methylation of CpG islands in the miR-9 promoter [63].

HULC was significantly up-regulated in osteosarcoma tissues and cell lines compared with normal controls. Overexpression of HULC was correlated with clinical stage and distant metastasis. Moreover, elevated expression of HULC was associated with lower survival rates in osteosarcoma patients. Suppression of HULC decreased cell proliferation, migration, invasion in osteosarcoma while the underlying mechanism is still not known. [65]

Metastasis-associated lung adenocarcinoma transcript 1 (MALAT-1)

MALAT-1 is also known as noncoding nuclear-enriched abundant transcript 2 (NEAT-2), a nuclear lncRNA with a length of $8.7 \mathrm{~kb}$ and located on chromosome 11q13 [66]. MALAT-1 was primarily identified in non-small cell lung cancer [66]. It was reported to be upregulated in lung, breast, pancreas, liver, colon, gastric, uterus, cervix and prostate cancers $[67,68]$. MALAT1 may serve as an independent prognostic biomarker for the survival of these cancers $[69,70]$.

MALAT- 1 acts as a transcriptional regulator for genes including those involved in cell proliferation, migration and metastasis [66]. MALAT1 functions as ceRNAs and regulates RNA transcription through competitively binding to common miRNAs, such as, cell division cycle 42 (cdc42) via miR-1 in breast cancer cells [71], MMP14 and Snail via miR-22 in human melanoma [72], SLUG via miR-204 in lung adenocarcinoma [73].

MALAT1 was significantly up-regulated in osteosarcoma tissues compared with paired non-tumor tissues. The expression of MALAT1 was remarkably associated with advanced clinical stage and distant metastasis of osteosarcoma patients [74] . Knockdown of MALAT1 inhibited the proliferation and invasion of human osteosarcoma cell and suppressed metastasis in vitro and in vivo. The expressions of PCNA, MMP-9, phosphorylated PI3Kp85 $\alpha$, and Akt were significantly reduced in MALAT1-deleted cells. MALAT1 might suppress the tumor growth and metastasis via PI3K/AKT signaling pathway[75] . Moreover, MALAT1 may also promote osteosarcoma development by acting as a ceRNA for miR376A to promote TGFA expression [76].

Taurine upregulated gene 1 (TUG1)

TUG1 is a 7.1-kb gene located on chromosome 22q12.2. The lncRNA was first identified in a genomic scan for genes upregulated in response to taurine treatment in developing mouse retinal cells [77]. TUG1 is upregulated in various human cancers, such as hepatocellular carcinoma, glioma, bladder cancer, esophageal squamous cell carcinoma, gastric cancer, ovarian cancer, renal cell carcinoma [78], but downregulated in non-small cell lung cancer and multiple myeloma [79, 80].

TUG1 promotes cell proliferation, migration and invasion, and suppresses apoptosis in human ovarian cancer cells, bladder cells, colorectal cancer cells [81, 82]. TUG1 mediates its biological functions at least in part through alteration of the protein expression levels of apoptosis-related mediators in ovarian cancer, chromatin remodeling and sequestration of miRNAs, e.g. miR-26/PTEN in human glioma cells [83], miR-145/ ZEB2 in bladder cancer cell [84].

TUG1 was significantly overexpressed in the osteosarcoma tissues compared with matched adjacent normal tissues. Upregulation of TUG1 was strongly correlated with poor prognosis and was an independent prognostic indicator for overall survival [85] . TUG1 knockdown inhibited cell proliferation, induced G0/G1 cell cycle arrest and apoptosis in vitro, and suppressed tumor growth in vivo in osteosarcoma cells. TUG1 acted as an endogenous 


\section{Cellular Physiology Cell Physiol Biochem 2017;42:1407-1419 \begin{tabular}{l|l} 
DOI: 10.1159/000479205 & $\begin{array}{l}\text { O 2017 The Author(s). Published by S. Karger AG, Basel } \\
\text { www.karger.com/cpb }\end{array}$
\end{tabular} \\ Li et al.: Long Noncoding RNAs in Osteosarcoma}

sponge to directly bind to miR-9-5p and downregulated miR-9-5p expression, leading to downregulation of POU2F1 and facilitating the tumorigenesis of osteosarcoma. [86]

Urothelial Carcinoma Associated 1 (UCA1)

UCA1, a 2314-bp IncRNA encoded on chromosome 19, was firstly identified in bladder cancer [87]. UCA1 expression was upregulated in many cancers, such as hepatocellular carcinoma, colorectal cancer, gastric cancer, esophageal squamous cell carcinoma and lung cancer [88-93]. Recently, some studies have also reported the relevance of UCA1 in acquired resistance to drugs $[87,94,95]$. Meta-analysis of studies available from various databases, e.g. PubMed, showed a significant negative association between UCA1 levels and overall survival time in different cancers, such as colorectal cancer, non-small cell lung cancer, gastric cancer, and ovarian cancer. The analysis suggested that high expression level of UCA1 was associated with poor clinical outcome $[87,96]$.

UCA1 was reported to regulate cell proliferation, invasion, apoptosis, and migration in various cancer. UCA1 promotes cancer cell proliferation by interacting with BRG1, hnRNP I, CREB or miR-216b. UCA1 increases drug resistance via SPRK1, Wnt6 and Wnt signaling pathway. Upregulation of UCA1 inhibits cell apoptosis via AKT-Bax- Bcl-2 signaling pathway. UCA1 promotes cancer metastasis by miR-216b-FGFR1-ERK signaling pathway $[88,97,98]$.

UCA1 expression was upregulated in osteosarcoma tissues and cell lines. High UCA1 expression was significantly correlated with large tumor size, high tumor grade, positive distant metastasis, and advanced clinical stage. UCA1 knockdown inhibited osteosarcoma cell proliferation, promoted cell apoptosis, and suppressed cell invasion and migration, whereas UCA1 overexpression showed opposite effects. The findings suggested that UCA1 may contribute to osteosarcoma initiation and progression, and would not only be a novel prognostic marker but also a potential therapeutic target for the disease [99] . However, the pathways identified in other cancers leading to biological effect of UCA1 are yet to be confirmed in osteosarcoma.

\section{Tumor Suppressor LncRNA in Osteosarcoma}

Loc285194

Loc285194, also called LSAMP antisense RNA3, consists of 4 exons with $2105 \mathrm{nt}$ in length and is located on chromosome 3q13.31 [100]. Recent studies showed that Loc285194 was down-regulated in several cancers such as esophageal squamous cell carcinoma, colorectal cancer, and plays key roles in tumor development and progression [101]. Loc285194 is a direct transcription target of p53 [102]. The lncRNA acts as a tumor suppressor in colon cancer cells, partly by repressing miR-211 through direct interaction. Moreover, miR-211 promotes cell growth, and at the same time, represses loc285194 expression through a reciprocal repression feedback loop[103] .

chr3q13.31 is also named as osteo3q13.31, the region harbors frequent focal copy number alterations and loss of heterozygosity in primary osteosarcoma [100]. Loc285194 showed loss of expression in primary osteosarcoma samples and cell lines. Depletion of Loc285194 promoted proliferation of normal osteoblasts through regulation of apoptotic and cell cycle transcripts as well as VEGF receptor 1 [100].

Maternally expressed gene 3 (MEG3)

MEG3 is an imprinted gene belonging to the imprinted DLK1-MEG3 locus located on chromosome 14q32.3 in humans [104]. The IncRNA is widely expressed in many human tissues but it is lost in many cancers due to hypermethylation at promoter or the intergenic region [105]. Reduced expression of MEG3 has been found in non-small cell lung cancer, bladder cancer, gastric cancer, colorectal cancer, breast cancer, prostate cancer and many other cancer tissues [106-112].

Ectopic expression of MEG3 in esophageal squamous carcinoma cell, gastric cancer cell, non-small cell lung cancer cells inhibited cell proliferation, promoted apoptosis, 
and suppressed metastasis. MEG3 induces accumulation of p53 protein, stimulates the transcription of p53-dependent promoters, and selectively regulates p53 target gene expression, e.g. MDM2 $[109,110,113]$. Overexpression of MEG3 also influenced the activity of Wnt/ $\beta$-catenin pathway in retinoblastoma cell lines [114], and reduced the level of miR21-5p expression in cervical cancer cells [115].

The expression levels of MEG3 were significantly reduced in cisplatin-resistant A549/DDP lung cancer cells, compared with those in parental A549 cells. Furthermore, upregulation of MEG3 re-sensitized the A549/DDP cells to cisplatin in vitro. MEG3-mediated chemosensitivity enhancement was associated with the induction of cell-cycle arrest and increased apoptosis, through regulation of p53, $\beta$-catenin and survivin, a target gene of the Wnt/ $\beta$-catenin signaling pathway $[107,116]$.\{Bian, 2016, LncRNA-UCA1 enhances cell proliferation and 5-fluorouracil resistance in colorectal cancer by inhibiting miR-204-5p\}

In osteosarcoma, the expression of MEG3 was clearly lower in osteosarcoma tissues compared with adjacent non-tumor tissues, and was associated with clinical stage and distant metastasis $(\mathrm{P}<0.05)$. However, the role of MEG3 in osteosarcoma development is not yet clear.

\section{Drug Associated LncRNA in Osteosarcoma}

Long intergenic non-protein coding RNA 161 (LINC00161)

LINC00161 is located on chromosome 21q21. LINC00161 was upregulated during cisplatin treatment in osteosarcoma cells. Overexpression of LINC00161 accelerated cisplatin-induced apoptosis and reduced chemoresistance in cells [117]. IFIT2, a target gene of miR-645 and a member of the IFN-induced gene family, promotes cancer apoptosis in oral squamous cell carcinoma [118] and in osteosarcoma cells [117]. Acting as a miR-645 sponge, LINC00161 increases IFIT2 protein level and thus promotes cell apoptosis in osteosarcoma cells [117].

Osteosarcoma doxorubicin resistance-related up-regulated IncRNA (ODRUL)

ODRUL was revealed by IncRNA microarray to be the most up-regulated lncRNA in human osteosarcoma doxorubicin resistant cell line MG63/DXR than its paternal cell line MG63. ODRUL was confirmed subsequently to be elevated in different doxorubicin-resistant osteosarcoma cell lines and reduced in different doxorubicin-sensitive osteosarcoma cell lines. Moreover, ODRUL was increased in specimens of osteosarcoma patients with a poor chemoresponse and lung metastasis. Knockdown of ODRUL inhibited cell proliferation, migration, and partly reversed doxorubicin resistance in vitro in osteosarcoma cells. The expression of classical drug resistance-related ATP-binding cassette, subfamily B, member 1 (ABCB1) gene was decreased after the ODRUL knockdown [119] . The lncRNA may serve as a novel target for reversing doxorubicin resistance in osteosarcoma.

\section{Future Perspectives}

\section{LncRNA as biomarker for osteosarcoma}

lncRNAs are involved in tumorigenesis, tumor cells proliferation, invasion, migration, apoptosis, and angiogenesis of osteosarcoma. They may be secreted and circulate in body fluids. The circulatory lncRNAs are strongly resistant to RNases and can be detected by PCR. Recent reports suggested that IncRNAs could be good candidates for tumor biomarkers and possessed high specificity, high sensitivity, and noninvasive characteristics [67, 120-123] . LncRNA PCA3 is highly expressed in prostate cancer [124]. The detection of PCA3 in the urine has been demonstrated to be a more specific marker to diagnose prostate cancer than the commonly used prostate- specific antigen (PSA) and already found wide application in prostate cancer [125-127]. Similarly, UCA1 transcript detected in urine was shown to be a highly sensitive and specific biomarker of bladder carcinoma [128]. HULC was detected

\section{KARGER}




\section{Cellular Physiology Cell Physiol Biochem 2017;42:1407-1419 \begin{tabular}{l|l} 
DOI: 10.1159/000479205 & O 2017 The Author(s). Published by S. Karger AG, Basel \\
www.karger.com/cpb
\end{tabular} \\ Li et al.: Long Noncoding RNAs in Osteosarcoma}

with high frequency in plasma of patients with hepatocellular carcinoma [57]. MALAT1 was detected in plasma as a biomarker for prostate cancer [129]. UCA1, HULC, MALAT1 are lncRNAs overexpressed in osteosarcoma. Therefore, it would be worthwhile to explore the potential use of these circulatory lncRNAs as biomarkers for osteosarcoma.

\section{LncRNA as therapeutic target for osteosarcoma}

LncRNAs play important role in the function and development of osteosarcoma, indicating they might be the potential therapeutic targets for treatment. IncRNA can be targeted by the use of small interfering RNA, antisense oligonucleotide, ribozyme, aptamer, miRNAs; such approaches have long been evaluated for targeting critical cancer-associated genes and they are in different phase of clinical trials [130]. Although therapy targeting IncRNAs is still in the infancy stage, further development in the way to target IncRNA for osteosarcoma treatment will likely be promising.

\section{Acknowledgements}

This work was supported by National Natural Science Foundation of China (81000821, 81672176).

\section{Disclosure Statement}

None.

\section{References}

1 Qi P, Du X: The long non-coding RNAs, a new cancer diagnostic and therapeutic gold mine. Mod Pathol 2013;26:155-165.

2 Costa FF: Non-coding RNAs: Meet thy masters. Bioessays 2010;32:599-608.

3 Zhang K, Shi ZM, Chang YN, Hu ZM, Qi HX, Hong W: The ways of action of long non-coding RNAs in cytoplasm and nucleus. Gene 2014;547:1-9. Chen LL: Linking Long Noncoding RNA Localization and Function. Trends Biochem Sci 2016;41:761-772. Ponting CP, Oliver PL, Reik W: Evolution and functions of long noncoding RNAs. Cell 2009;136:629-641. Schaukowitch K, Kim TK: Emerging epigenetic mechanisms of long non-coding RNAs. Neuroscience 2014;264:25-38.

7 Yoon JH, Abdelmohsen K, Gorospe M: Functional interactions among microRNAs and long noncoding RNAs. Semin Cell Dev Biol 2014;34:9-14.

-8 Yoon JH, Abdelmohsen K, Gorospe M: Post-transcriptional gene regulation by long noncoding RNA. J Mol Biol 2013;425:3723-3730.

-9 Mirabello L, Troisi RJ, Savage SA: Osteosarcoma incidence and survival rates from 1973 to 2004: data from the Surveillance, Epidemiology, and End Results Program. Cancer 2009;115:1531-1543.

10 Bielack SS, Kempf-Bielack B, Delling G, Exner GU, Flege S, Helmke K, Kotz R, Salzer-Kuntschik M, Werner M, Winkelmann W, Zoubek A, Jurgens H, Winkler K, Cooperative German Austrian S: Prognostic factors in high-grade osteosarcoma of the extremities or trunk: An analysis of 1,702 patients treated on neoadjuvant cooperative osteosarcoma study group protocols. J Clin Oncol 2002;20:776-790.

-11 Ferrari S, Smeland S, Mercuri M, Bertoni F, Longhi A, Ruggieri P, Alvegard TA, Picci P, Capanna R, Bernini G, Müller C, Tienghi A, Wiebe T, Comandone A, Böhling T, Del Prever AB, Brosjö O, Bacci G, Saeter G, Groups IaSS: Neoadjuvant chemotherapy with high-dose Ifosfamide, high-dose methotrexate, cisplatin, and doxorubicin for patients with localized osteosarcoma of the extremity: a joint study by the Italian and Scandinavian Sarcoma Groups. J Clin Oncol 2005;23:8845-8852.

-12 Wu D, Chen K, Bai Y, Zhu X, Chen Z, Wang C, Zhao Y, Li M: Screening of diagnostic markers for osteosarcoma. Mol Med Rep 2014;10:2415-2420.

13 Kong C, Hansen MF: Biomarkers in Osteosarcoma. Expert Opin Med Diagn 2009;3:13-23.

14 Luetke A, Meyers PA, Lewis I, Juergens H: Osteosarcoma treatment - where do we stand? A state of the art review. Cancer Treat Rev 2014;40:523-532.

-15 Huarte M: The emerging role of IncRNAs in cancer. Nat Med 2015;21:1253-1261. 


\section{Cellular Physiology Cell Physiol Biochem 2017;42:1407-1419 \begin{tabular}{ll|l} 
and Biochemistry $\begin{array}{l}\text { DOI:1159/000479205 } \\
\text { Published online: July 17, } 2017\end{array}$ & $\begin{array}{l}\text { @ } 2017 \text { The Author(s). Published by S. Karger AG, Basel } \\
\text { www.karger.com/cpb }\end{array}$ \\
\hline
\end{tabular}}

Li et al.: Long Noncoding RNAs in Osteosarcoma

16 Li Z, Yu X, Shen J: Long non-coding RNAs: emerging players in osteosarcoma. Tumour Biol 2016;37:28112816.

17 Chen J, Lin C, Yong W, Ye Y, Huang Z: Calycosin and genistein induce apoptosis by inactivation of HOTAIR/pAkt signaling pathway in human breast cancer MCF-7 cells. Cell Physiol Biochem 2015;35:722-728.

18 Chen Y, Li C, Pan Y, Han S, Feng B, Gao Y, Chen J, Zhang K, Wang R, Chen L: The Emerging Role and Promise of Long Noncoding RNAs in Lung Cancer Treatment. Cell Physiol Biochem 2016;38:2194-2206.

19 Dong L, Ni J, Hu W, Yu C, Li H: Upregulation of Long Non-Coding RNA PlncRNA-1 Promotes Metastasis and Induces Epithelial-Mesenchymal Transition in Hepatocellular Carcinoma. Cell Physiol Biochem 2016;38:836-846.

20 Li C, Chen J, Zhang K, Feng B, Wang R, Chen L: Progress and Prospects of Long Noncoding RNAs (lncRNAs) in Hepatocellular Carcinoma. Cell Physiol Biochem 2015;36:423-434.

-21 Pan Y, Li C, Chen J, Zhang K, Chu X, Wang R, Chen L: The Emerging Roles of Long Noncoding RNA ROR (lincRNA-ROR) and its Possible Mechanisms in Human Cancers. Cell Physiol Biochem 2016;40:219-229.

-22 Wang D, Wang N, Long Z, Ren X: Long Non-Coding RNA BANCR Promotes Endometrial Cancer Cell Proliferation and Invasion by Regulating MMP2 and MMP1 via ERK/MAPK Signaling Pathway. Cell Physiol Biochem 2016;40:644-656.

-23 Wang F, Yang H, Deng Z, Su Y, Fang Q, Yin Z: HOX Antisense lincRNA HOXA-AS2 Promotes Tumorigenesis of Hepatocellular Carcinoma. Cell Physiol Biochem 2016;40:287-296.

24 Wang L, Chen Z, An L, Wang Y, Zhang Z, Guo Y, Liu C: Analysis of Long Non-Coding RNA Expression Profiles in Non-Small Cell Lung Cancer. Cell Physiol Biochem 2016;38:2389-2400.

25 Xu B, Shao Q, Xie K, Zhang Y, Dong T, Xia Y, Tang W: The Long Non-Coding RNA ENST00000537266 and ENST00000426615 Influence Papillary Thyroid Cancer Cell Proliferation and Motility. Cell Physiol Biochem 2016;38:368-378.

-26 Xu CZ, Jiang C, Wu Q Liu L, Yan X, Shi R: A Feed-Forward Regulatory Loop between HuR and the Long Noncoding RNA HOTAIR Promotes Head and Neck Squamous Cell Carcinoma Progression and Metastasis. Cell Physiol Biochem 2016;40:1039-1051.

-27 Huang R, Wang X, Zhang W, Zhangyuan G, Jin K, Yu W, Xie Y, Xu X, Wang H, Sun B: Down-Regulation of LncRNA DGCR5 Correlates with Poor Prognosis in Hepatocellular Carcinoma. Cell Physiol Biochem 2016;40:707-715.

-28 Yang ZT, Li Z, Wang XG, Tan T, Yi F, Zhu H, Zhao JP, Zhou XF: Overexpression of Long Non-Coding RNA ZXF2 Promotes Lung Adenocarcinoma Progression Through c-Myc Pathway. Cell Physiol Biochem 2015;35:23602370.

-29 Zhou X, Ye F, Yin C, Zhuang Y, Yue G, Zhang G: The Interaction Between MiR-141 and lncRNA-H19 in Regulating Cell Proliferation and Migration in Gastric Cancer. Cell Physiol Biochem 2015;36:1440-1452.

-30 Berteaux N, Aptel N, Cathala G, Genton C, Coll J, Daccache A, Spruyt N, Hondermarck H, Dugimont T, Curgy JJ, Forné T, Adriaenssens E: A novel H19 antisense RNA overexpressed in breast cancer contributes to paternal IGF2 expression. Mol Cell Biol 2008;28:6731-6745.

-31 Gao T, He B, Pan Y, Xu Y, Li R, Deng Q, Sun H, Wang S: Long non-coding RNA 91H contributes to the occurrence and progression of esophageal squamous cell carcinoma by inhibiting IGF2 expression. Mol Carcinog 2015;54:359-367.

32 Deng Q He B, Gao T, Pan Y, Sun H, Xu Y, Li R, Ying H, Wang F, Liu X, Chen J, Wang S: Up-regulation of 91H promotes tumor metastasis and predicts poor prognosis for patients with colorectal cancer. PLoS One 2014;9:e103022.

33 Xia WK, Lin QF, Shen D, Liu ZL, Su J, Mao WD: Clinical implication of long noncoding RNA 91H expression profile in osteosarcoma patients. Onco Targets Ther 2016;9:4645-4652.

-34 Meijer D, van Agthoven T, Bosma PT, Nooter K, Dorssers LC: Functional screen for genes responsible for tamoxifen resistance in human breast cancer cells. Mol Cancer Res 2006;4:379-386.

-35 Godinho M, Meijer D, Setyono-Han B, Dorssers LC, van Agthoven T: Characterization of BCAR4, a novel oncogene causing endocrine resistance in human breast cancer cells. J Cell Physiol 2011;226:1741-1749.

-36 Xing Z, Lin A, Li C, Liang K, Wang S, Liu Y, Park PK, Qin L, Wei Y, Hawke DH, Hung MC, Lin C, Yang L: IncRNA directs cooperative epigenetic regulation downstream of chemokine signals. Cell 2014;159:1110-1125.

-37 Godinho MF, Wulfkuhle JD, Look MP, Sieuwerts AM, Sleijfer S, Foekens JA, Petricoin EF, Dorssers LC, van Agthoven T: BCAR4 induces antioestrogen resistance but sensitises breast cancer to lapatinib. Br J Cancer 2012;107:947-955.

-38 Chen F, Mo J, Zhang L: Long noncoding RNA BCAR4 promotes osteosarcoma progression through activating GLI2-dependent gene transcription. Tumour Biol 2016;37:13403-13412. 


\section{Cellular Physiology Cell Physiol Biochem 2017;42:1407-1419 \begin{tabular}{ll|l} 
and Biochemistry Published online: July 17, 2017 & $\begin{array}{l}\text { C) } 2017 \text { The Author(s). Published by S. Karger AG, Basel } \\
\text { www.karger.com/cpb }\end{array}$ \\
\hline
\end{tabular}}

Li et al.: Long Noncoding RNAs in Osteosarcoma

39 Xing Z, Park PK, Lin C, Yang L: LncRNA BCAR4 wires up signaling transduction in breast cancer. RNA Biol 2015;12:681-689.

40 Sun J, Wang X, Fu C, Zou J, Hua H, Bi Z: Long noncoding RNA FGFR3-AS1 promotes osteosarcoma growth through regulating its natural antisense transcript FGFR3. Mol Biol Rep 2016;43:427-436.

41 Katoh M, Nakagama H: FGF receptors: cancer biology and therapeutics. Med Res Rev 2014;34:280-300.

42 Yao J, Li J, Geng P, Li Y, Chen H, Zhu Y: Knockdown of a HIF-2alpha promoter upstream long noncoding RNA impairs colorectal cancer stem cell properties in vitro through HIF-2alpha downregulation. Onco Targets Ther 2015;8:3467-3474.

43 Li W, He X, Xue R, Zhang Y, Zhang X, Lu J, Zhang Z, Xue L: Combined over-expression of the hypoxiainducible factor $2 \alpha$ gene and its long non-coding RNA predicts unfavorable prognosis of patients with osteosarcoma. Pathol Res Pract 2016;212:861-866.

-44 Wang Y, Yao J, Meng H, Yu Z, Wang Z, Yuan X, Chen H, Wang A: A novel long non-coding RNA, hypoxiainducible factor-2alpha promoter upstream transcript, functions as an inhibitor of osteosarcoma stem cells in vitro. Mol Med Rep 2015;11:2534-2540.

45 Preker P, Almvig K, Christensen MS, Valen E, Mapendano CK, Sandelin A, Jensen TH: PROMoter uPstream Transcripts share characteristics with mRNAs and are produced upstream of all three major types of mammalian promoters. Nucleic Acids Res 2011;39:7179-7193.

-46 Taft RJ, Kaplan CD, Simons C, Mattick JS: Evolution, biogenesis and function of promoter-associated RNAs. Cell Cycle 2009;8:2332-2338.

47 Cheng Y, Jutooru I, Chadalapaka G, Corton JC, Safe S: The long non-coding RNA HOTTIP enhances pancreatic cancer cell proliferation, survival and migration. Oncotarget 2015;6:10840-10852.

48 Sang Y, Zhou F, Wang D, Bi X, Liu X, Hao Z, Li Q, Zhang W: Up-regulation of long non-coding HOTTIP functions as an oncogene by regulating HOXA13 in non-small cell lung cancer. Am J Transl Res 2016;8:2022-2032.

-49 Zhang H, Zhao L, Wang YX, Xi M, Liu SL, Luo LL: Long non-coding RNA HOTTIP is correlated with progression and prognosis in tongue squamous cell carcinoma. Tumour Biol 2015;36:8805-8809.

50 Ren YK, Xiao Y, Wan XB, Zhao YZ, Li J, Li Y, Han GS, Chen XB, Zou QY, Wang GC, Lu CM, Xu YC, Wang YC: Association of long non-coding RNA HOTTIP with progression and prognosis in colorectal cancer. Int J Clin Exp Pathol 2015;8:11458-11463.

51 Ye H, Liu K, Qian K: Overexpression of long noncoding RNA HOTTIP promotes tumor invasion and predicts poor prognosis in gastric cancer. Onco Targets Ther 2016;9:2081-2088.

-52 Wu L, Candille SI, Choi Y, Xie D, Jiang L, Li-Pook-Than J, Tang H, Snyder M: Variation and genetic control of protein abundance in humans. Nature 2013;499:79-82.

53 Quagliata L, Matter MS, Piscuoglio S, Arabi L, Ruiz C, Procino A, Kovac M, Moretti F, Makowska Z, Boldanova T, Andersen JB, Hammerle M, Tornillo L, Heim MH, Diederichs S, Cillo C, Terracciano LM: Long noncoding RNA HOTTIP/HOXA13 expression is associated with disease progression and predicts outcome in hepatocellular carcinoma patients. Hepatology 2014;59:911-923.

54 Li F, Cao L, Hang D, Wang F, Wang Q: Long non-coding RNA HOTTIP is up-regulated and associated with poor prognosis in patients with osteosarcoma. Int J Clin Exp Pathol 2015;8:11414-11420.

55 Li Z, Zhao L, Wang Q: Overexpression of long non-coding RNA HOTTIP increases chemoresistance of osteosarcoma cell by activating the Wnt/beta-catenin pathway. Am J Transl Res 2016;8:2385-2393.

56 Hämmerle M, Gutschner T, Uckelmann H, Ozgur S, Fiskin E, Gross M, Skawran B, Geffers R, Longerich T, Breuhahn K, Schirmacher P, Stoecklin G, Diederichs S: Posttranscriptional destabilization of the liver-specific long noncoding RNA HULC by the IGF2 mRNA-binding protein 1 (IGF2BP1). Hepatology 2013;58:1703-1712.

-57 Xie H, Ma H, Zhou D: Plasma HULC as a promising novel biomarker for the detection of hepatocellular carcinoma. Biomed Res Int 2013;2013:136106.

58 Li J, Wang X, Tang J, Jiang R, Zhang W, Ji J, Sun B: HULC and Linc00152 Act as Novel Biomarkers in Predicting Diagnosis of Hepatocellular Carcinoma. Cell Physiol Biochem 2015;37:687-696.

59 Jin C, Shi W, Wang F, Shen X, Qi J, Cong H, Yuan J, Shi L, Zhu B, Luo X, Zhang Y, Ju S: Long non-coding RNA HULC as a novel serum biomarker for diagnosis and prognosis prediction of gastric cancer. Oncotarget 2016;7:51763-51772.

-60 Peng W, Wu J, Feng J: Long noncoding RNA HULC predicts poor clinical outcome and represents prooncogenic activity in diffuse large B-cell lymphoma. Biomed Pharmacother 2016;79:188-193.

61 Yang XJ, Huang CQ, Peng CW, Hou JX, Liu JY: Long noncoding RNA HULC promotes colorectal carcinoma progression through epigenetically repressing NKD2 expression. Gene 2016;592:172-178. 


\section{Cellular Physiology Cell Physiol Biochem 2017;42:1407-1419 \begin{tabular}{l|l|l} 
and Biochemistry 10.1159/000479205 & $\begin{array}{l}\text { ( ) 2017 The Author(s). Published by S. Karger AG, Basel } \\
\text { www.karger.com/cpb }\end{array}$
\end{tabular}}

Li et al.: Long Noncoding RNAs in Osteosarcoma

-62 Lu Z, Xiao Z, Liu F, Cui M, Li W, Yang Z, Li J, Ye L, Zhang X: Long non-coding RNA HULC promotes tumor angiogenesis in liver cancer by up-regulating sphingosine kinase 1 (SPHK1). Oncotarget 2016;7:241-254.

63 Cui M, Xiao Z, Wang Y, Zheng M, Song T, Cai X, Sun B, Ye L, Zhang X: Long noncoding RNA HULC modulates abnormal lipid metabolism in hepatoma cells through an miR-9-mediated RXRA signaling pathway. Cancer Res 2015;75:846-857.

64 Li SP, Xu HX, Yu Y, He JD, Wang Z, Xu YJ, Wang CY, Zhang HM, Zhang RX, Zhang JJ, Yao Z, Shen ZY: LncRNA HULC enhances epithelial-mesenchymal transition to promote tumorigenesis and metastasis of hepatocellular carcinoma via the miR-200a-3p/ZEB1 signaling pathway. Oncotarget 2016;7:42431-42446.

65 Sun XH, Yang LB, Geng XL, Wang R, Zhang ZC: Increased expression of IncRNA HULC indicates a poor prognosis and promotes cell metastasis in osteosarcoma. Int J Clin Exp Pathol 2015;8:2994-3000.

-66 Ji P, Diederichs S, Wang W, Böing S, Metzger R, Schneider PM, Tidow N, Brandt B, Buerger H, Bulk E, Thomas M, Berdel WE, Serve H, Müller-Tidow C: MALAT-1, a novel noncoding RNA, and thymosin beta4 predict metastasis and survival in early-stage non-small cell lung cancer. Oncogene 2003;22:8031-8041.

67 Shi T, Gao G, Cao Y: Long Noncoding RNAs as Novel Biomarkers Have a Promising Future in Cancer Diagnostics. Dis Markers 2016;2016:9085195.

68 Li T, Mo X, Fu L, Xiao B, Guo J: Molecular mechanisms of long noncoding RNAs on gastric cancer. Oncotarget 2016;7:8601-8612.

69 Tian X, Xu G: Clinical value of lncRNA MALAT1 as a prognostic marker in human cancer: systematic review and meta-analysis. BMJ Open 2015;5:e008653.

70 Zhu L, Liu J, Ma S, Zhang S: Long Noncoding RNA MALAT-1 Can Predict Metastasis and a Poor Prognosis: a Meta-Analysis. Pathol Oncol Res 2015;21:1259-1264.

71 Chou J, Wang B, Zheng T, Li X, Zheng L, Hu J, Zhang Y, Xing Y, Xi T: MALAT1 induced migration and invasion of human breast cancer cells by competitively binding miR-1 with cdc42. Biochem Biophys Res Commun 2016;472:262-269.

72 Luan W, Li L, Shi Y, Bu X, Xia Y, Wang J, Djangmah HS, Liu X, You Y, Xu B: Long non-coding RNA MALAT1 acts as a competing endogenous RNA to promote malignant melanoma growth and metastasis by sponging miR-22. Oncotarget 2016;7:63901-63912.

73 Li J, Wang J, Chen Y, Li S, Jin M, Wang H, Chen Z, Yu W: LncRNA MALAT1 exerts oncogenic functions in lung adenocarcinoma by targeting miR-204. Am J Cancer Res 2016;6:1099-1107.

74 Gao KT, Lian D: Long non-coding RNA MALAT1 is an independent prognostic factor of osteosarcoma. Eur Rev Med Pharmacol Sci 2016;20:3561-3565.

-75 Dong Y, Liang G, Yuan B, Yang C, Gao R, Zhou X: MALAT1 promotes the proliferation and metastasis of osteosarcoma cells by activating the PI3K/Akt pathway. Tumour Biol 2015;36:1477-1486.

-76 Luo W, He H, Xiao W, Liu Q Deng Z, Lu Y, Wang Q, Zheng Q Li Y: MALAT1 promotes osteosarcoma development by targeting TGFA via MIR376A. Oncotarget 2016;7:54733-54743.

77 Young TL, Matsuda T, Cepko CL: The noncoding RNA taurine upregulated gene 1 is required for differentiation of the murine retina. Curr Biol 2005;15:501-512.

78 Zhang M, Lu W, Huang Y, Shi J, Wu X, Zhang X, Jiang R, Cai Z, Wu S: Downregulation of the long noncoding RNA TUG1 inhibits the proliferation, migration, invasion and promotes apoptosis of renal cell carcinoma. J Mol Histol 2016;47:421-428.

-79 Isin M, Ozgur E, Cetin G, Erten N, Aktan M, Gezer U, Dalay N: Investigation of circulating IncRNAs in B-cell neoplasms. Clin Chim Acta 2014;431:255-259.

80 Zhang EB, Yin DD, Sun M, Kong R, Liu XH, You LH, Han L, Xia R, Wang KM, Yang JS, De W, Shu YQ Wang ZX: P53-regulated long non-coding RNA TUG1 affects cell proliferation in human non-small cell lung cancer, partly through epigenetically regulating HOXB7 expression. Cell Death Dis 2014;5:e1243.

-81 Kuang D, Zhang X, Hua S, Dong W, Li Z: Long non-coding RNA TUG1 regulates ovarian cancer proliferation and metastasis via affecting epithelial-mesenchymal transition. Exp Mol Pathol 2016;101:267-273.

-82 Iliev R, Kleinova R, Juracek J, Dolezel J, Ozanova Z, Fedorko M, Pacik D, Svoboda M, Stanik M, Slaby O: Overexpression of long non-coding RNA TUG1 predicts poor prognosis and promotes cancer cell proliferation and migration in high-grade muscle-invasive bladder cancer. Tumour Biol 2016;37:1338513390.

83 Li J, An G, Zhang M, Ma Q: Long non-coding RNA TUG1 acts as a miR-26a sponge in human glioma cells. Biochem Biophys Res Commun 2016;477:743-748.

-84 Tan J, Qiu K, Li M, Liang Y: Double-negative feedback loop between long non-coding RNA TUG1 and miR145 promotes epithelial to mesenchymal transition and radioresistance in human bladder cancer cells. FEBS Lett 2015;589:3175-3181. 


\section{Cellular Physiology Cell Physiol Biochem 2017;42:1407-1419 \begin{tabular}{ll|l} 
and Biochemistry Published online: July 17, 2017 & $\begin{array}{l}\text { (C) } 2017 \text { The Author(s). Published by S. Karger AG, Basel } \\
\text { www.karger.com/cpb }\end{array}$ \\
\hline
\end{tabular}}

Li et al.: Long Noncoding RNAs in Osteosarcoma

85 Ma B, Li M, Zhang L, Huang M, Lei JB, Fu GH, Liu CX, Lai QW, Chen QQ, Wang YL: Upregulation of long non-coding RNA TUG1 correlates with poor prognosis and disease status in osteosarcoma. Tumour Biol 2016;37:4445-4455.

-86 Xie CH, Cao YM, Huang Y, Shi QW, Guo JH, Fan ZW, Li JG, Chen BW, Wu BY: Long non-coding RNA TUG1 contributes to tumorigenesis of human osteosarcoma by sponging miR-9-5p and regulating POU2F1 expression. Tumour Biol 2016;37:15031-15041.

87 Xue M, Chen W, Li X: Urothelial cancer associated 1: a long noncoding RNA with a crucial role in cancer. J Cancer Res Clin Oncol 2016;142:1407-1419.

-88 Wang F, Ying HQ, He BS, Pan YQ Deng QW, Sun HL, Chen J, Liu X, Wang SK: Upregulated lncRNA-UCA1 contributes to progression of hepatocellular carcinoma through inhibition of miR-216b and activation of FGFR1/ERK signaling pathway. Oncotarget 2015;6:7899-7917.

89 Bian Z, Jin L, Zhang J, Yin Y, Quan C, Hu Y, Feng Y, Liu H, Fei B, Mao Y, Zhou L, Qi X, Huang S, Hua D, Xing C, Huang Z: LncRNA-UCA1 enhances cell proliferation and 5-fluorouracil resistance in colorectal cancer by inhibiting miR-204-5p. Sci Rep 2016;6:23892.

-90 Ni B, Yu X, Guo X, Fan X, Yang Z, Wu P, Yuan Z, Deng Y, Wang J, Chen D, Wang L: Increased urothelial cancer associated 1 is associated with tumor proliferation and metastasis and predicts poor prognosis in colorectal cancer. Int J Oncol 2015;47:1329-1338.

-91 Li JY, Ma X, Zhang CB: Overexpression of long non-coding RNA UCA1 predicts a poor prognosis in patients with esophageal squamous cell carcinoma. Int J Clin Exp Pathol 2014;7:7938-7944.

-92 Zheng Q, Wu F, Dai WY, Zheng DC, Zheng C, Ye H, Zhou B, Chen JJ, Chen P: Aberrant expression of UCA1 in gastric cancer and its clinical significance. Clin Transl Oncol 2015;17:640-646.

93 Han Y, Yang YN, Yuan HH, Zhang TT, Sui H, Wei XL, Liu L, Huang P, Zhang WJ, Bai YX: UCA1, a long noncoding RNA up-regulated in colorectal cancer influences cell proliferation, apoptosis and cell cycle distribution. Pathology 2014;46:396-401.

-94 Hong HH, Hou LK, Pan X, Wu CY, Huang H, Li B, Nie W: Long non-coding RNA UCA1 is a predictive biomarker of cancer. Oncotarget 2016;7:44442-44447.

$\$ 95$ Li F, Hu CP: Long Non-Coding RNA Urothelial Carcinoma Associated 1 (UCA1): Insight into Its Role in Human Diseases. Crit Rev Eukaryot Gene Expr 2015;25:191-197.

$\$ 96$ Liu FT, Zhu PQ, Luo HL, Zhang Y, Qiu C: Prognostic value of long non-coding RNA UCA1 in human solid tumors. Oncotarget 2016;7:57991-58000.

97 Wang X, Gong Y, Jin B, Wu C, Yang J, Wang L, Zhang Z, Mao Z: Long non-coding RNA urothelial carcinoma associated 1 induces cell replication by inhibiting BRG1 in 5637 cells. Oncol Rep 2014;32:1281-1290.

98 Huang J, Zhou N, Watabe K, Lu Z, Wu F, Xu M, Mo YY: Long non-coding RNA UCA1 promotes breast tumor growth by suppression of p27 (Kip1). Cell Death Dis 2014;5:e1008.

-99 Li W, Xie P, Ruan WH: Overexpression of IncRNA UCA1 promotes osteosarcoma progression and correlates with poor prognosis. J Bone Oncol 2016;5:80-85.

100 Pasic I, Shlien A, Durbin AD, Stavropoulos DJ, Baskin B, Ray PN, Novokmet A, Malkin D: Recurrent focal copy-number changes and loss of heterozygosity implicate two noncoding RNAs and one tumor suppressor gene at chromosome 3q13.31 in osteosarcoma. Cancer Res 2010;70:160-171.

101 Tong YS, Zhou XL, Wang XW, Wu QQ Yang TX, Lv J, Yang JS, Zhu B, Cao XF: Association of decreased expression of long non-coding RNA LOC285194 with chemoradiotherapy resistance and poor prognosis in esophageal squamous cell carcinoma. J Transl Med 2014;12:233.

102 Liu Q, Huang J, Zhou N, Zhang Z, Zhang A, Lu Z, Wu F, Mo YY: LncRNA loc285194 is a p53-regulated tumor suppressor. Nucleic Acids Res 2013;41:4976-4987.

103 Salmena L, Poliseno L, Tay Y, Kats L, Pandolfi PP: A ceRNA hypothesis: the Rosetta Stone of a hidden RNA language? Cell 2011;146:353-358.

104 da Rocha ST, Edwards CA, Ito M, Ogata T, Ferguson-Smith AC: Genomic imprinting at the mammalian Dlk1Dio3 domain. Trends Genet 2008;24:306-316.

105 Benetatos L, Vartholomatos G, Hatzimichael E: MEG3 imprinted gene contribution in tumorigenesis. Int J Cancer 2011;129:773-779.

106 Zhou Y, Zhang X, Klibanski A: MEG3 noncoding RNA: a tumor suppressor. J Mol Endocrinol 2012;48:R4553.

107 Xia Y, He Z, Liu B, Wang P, Chen Y: Downregulation of Meg3 enhances cisplatin resistance of lung cancer cells through activation of the WNT/ $\beta$-catenin signaling pathway. Mol Med Rep 2015;12:4530-4537.

108 Ying L, Huang Y, Chen H, Wang Y, Xia L, Chen Y, Liu Y, Qiu F: Downregulated MEG3 activates autophagy and increases cell proliferation in bladder cancer. Mol Biosyst 2013;9:407-411. 


\section{Cellular Physiology Cell Physiol Biochem 2017;42:1407-1419

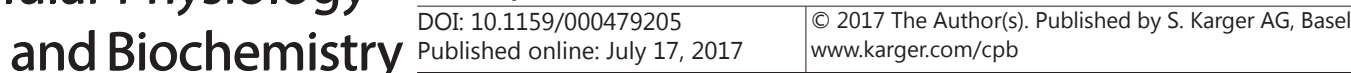

Li et al.: Long Noncoding RNAs in Osteosarcoma

109 Sun M, Xia R, Jin F, Xu T, Liu Z, De W, Liu X: Downregulated long noncoding RNA MEG3 is associated with poor prognosis and promotes cell proliferation in gastric cancer. Tumour Biol 2014;35:1065-1073.

110 Lu KH, Li W, Liu XH, Sun M, Zhang ML, Wu WQ Xie WP, Hou YY: Long non-coding RNA MEG3 inhibits NSCLC cells proliferation and induces apoptosis by affecting p53 expression. BMC Cancer 2013;13:461.

111 Yin DD, Liu ZJ, Zhang E, Kong R, Zhang ZH, Guo RH: Decreased expression of long noncoding RNA MEG3 affects cell proliferation and predicts a poor prognosis in patients with colorectal cancer. Tumour Biol 2015;36:4851-4859.

112 Luo G, Wang M, Wu X, Tao D, Xiao X, Wang L, Min F, Zeng F, Jiang G: Long Non-Coding RNA MEG3 Inhibits Cell Proliferation and Induces Apoptosis in Prostate Cancer. Cell Physiol Biochem 2015;37:2209-2220.

113 Lv D, Sun R, Yu Q, Zhang X: The long non-coding RNA maternally expressed gene 3 activates p53 and is downregulated in esophageal squamous cell cancer. Tumour Biol 2016

114 Gao Y, Lu X: Decreased expression of MEG3 contributes to retinoblastoma progression and affects retinoblastoma cell growth by regulating the activity of Wnt/ $\beta$-catenin pathway. Tumour Biol 2016;37:1461-1469.

115 Zhang J, Yao T, Wang Y, Yu J, Liu Y, Lin Z: Long noncoding RNA MEG3 is downregulated in cervical cancer and affects cell proliferation and apoptosis by regulating miR-21. Cancer Biol Ther 2016;17:104-113.

116 Liu J, Wan L, Lu K, Sun M, Pan X, Zhang P, Lu B, Liu G, Wang Z: The Long Noncoding RNA MEG3 Contributes to Cisplatin Resistance of Human Lung Adenocarcinoma. PLoS One 2015;10:e0114586.

117 Wang Y, Zhang L, Zheng X, Zhong W, Tian X, Yin B, Tian K, Zhang W: Long non-coding RNA LINC00161 sensitises osteosarcoma cells to cisplatin-induced apoptosis by regulating the miR-645-IFIT2 axis. Cancer Lett 2016;382:137-146.

118 Reich NC: A death-promoting role for ISG54/IFIT2. J Interferon Cytokine Res 2013;33:199-205.

119 Zhang CL, Zhu KP, Shen GQ Zhu ZS: A long non-coding RNA contributes to doxorubicin resistance of osteosarcoma. Tumour Biol 2016;37:2737-2748.

120 Yarmishyn AA, Kurochkin IV: Long noncoding RNAs: a potential novel class of cancer biomarkers. Front Genet 2015;6:145.

121 Hu HB, Jie HY, Zheng XX: Three Circulating LncRNA Predict Early Progress of Esophageal Squamous Cell Carcinoma. Cell Physiol Biochem 2016;40:117-125.

122 Qiu ZL, Shen CT, Sun ZK, Wei WJ, Zhang XY, Song HJ, Luo QY: Circulating Long Non-Coding RNAs Act as Biomarkers for Predicting 131I Uptake and Mortality in Papillary Thyroid Cancer Patients with Lung Metastases. Cell Physiol Biochem 2016;40:1377-1390.

123 Tang Q, Ni Z, Cheng Z, Xu J, Yu H, Yin P: Three circulating long non-coding RNAs act as biomarkers for predicting NSCLC. Cell Physiol Biochem 2015;37:1002-1009.

124 de Kok JB, Verhaegh GW, Roelofs RW, Hessels D, Kiemeney LA, Aalders TW, Swinkels DW, Schalken JA: DD3(PCA3), a very sensitive and specific marker to detect prostate tumors. Cancer Res 2002;62:26952698.

125 Hessels D, Klein Gunnewiek JM, van Oort I, Karthaus HF, van Leenders GJ, van Balken B, Kiemeney LA, Witjes JA, Schalken JA: DD3(PCA3)-based molecular urine analysis for the diagnosis of prostate cancer. Eur Urol 2003;44:8-15; discussion 15-16.

-126 Tinzl M, Marberger M, Horvath S, Chypre C: DD3PCA3 RNA analysis in urine--a new perspective for detecting prostate cancer. Eur Urol 2004;46:182-186; discussion 187.

127 Lee GL, Dobi A, Srivastava S: Prostate cancer: diagnostic performance of the PCA3 urine test. Nat Rev Urol 2011;8:123-124.

-128 Wang XS, Zhang Z, Wang HC, Cai JL, Xu QW, Li MQ, Chen YC, Qian XP, Lu TJ, Yu LZ, Zhang Y, Xin DQ Na YQ, Chen WF: Rapid identification of UCA1 as a very sensitive and specific unique marker for human bladder carcinoma. Clin Cancer Res 2006;12:4851-4858.

129 Ren S, Liu Y, Xu W, Sun Y, Lu J, Wang F, Wei M, Shen J, Hou J, Gao X, Xu C, Huang J, Zhao Y: Long noncoding RNA MALAT-1 is a new potential therapeutic target for castration resistant prostate cancer. J Urol 2013;190:2278-2287.

130 Slaby O: Non-coding RNAs as Biomarkers for Colorectal Cancer Screening and Early Detection. Adv Exp Med Biol 2016;937:153-170. 